\title{
Kinerja Penyuluhan di Nusa Tenggara Timur
}

\section{The Performance of The Agricultural Extension In East Nusa Tenggara Province}

\author{
Jelamu Ardu Marius $^{1 *}$, Sumardjo $^{2}$, Margono Slamet ${ }^{2}$, dan Pang S.Asngari ${ }^{2}$ \\ ${ }^{1}$ Pemda Nusa Tenggara Timur \\ ${ }^{2}$ Departemen Sains Komunikasi dan Pengembangan Masyarakat, \\ Fakultas Ekologi Manusia, Institut Pertanian Bogor
}

\begin{abstract}
The objectives of this research were to portray the influence of internal and external factors to the performance of the agricultural extension. The individual characrterization of the agricultural extension agents were the internal factors which assumed to influence toward the performance of agricultural extension and those other i.e the non formal extension education (diklat), the milieu, and the extension organization structure were the external factors. The respondents were selected by the random and purposive sampling method in the three regency as research area. Data analysis was done by using descriptive and Linear Structural Relationship (LISREL) program 8.72 by Structural Equation Modelling (SEM) models. The results of the research showed that the non formal extension education and the extension organization structure were influenced positively and significantly to the performacen of extension (external factors), but those other were not.
\end{abstract}

Key words: competence, agricultural extension agent, farmer, perception, autonomy

\section{PENDAHULUAN}

Penyuluhan yang diberikan kepada petani yang selama ini kita kenal bertujuan untuk: (1) memampukan petani bertani lebih baik (better farming), (2) memampukan petani berusahatani lebih baik (better business) dan (3) memampukan petani mencapai kehidupan yang lebih baik (better living). Dalam sejarah pembangunan pertanian di Indonesia sejak zaman Belanda sampai dengan sekarang kegiatan penyuluhan merupakan salah satu penentu keberhasilan pembangunan pertanian. Di tahun 1980-an Indonesia pernah mencatat keberhasilannya sebagai negara swasembada pangan khususnya beras karena intensifnya kegiatan penyuluhan yang dilakukan di seluruh Indonesia. Salah satu penentu keberhasilan pembangunan pertanian itu adalah peran penyuluh. Kemampuan penyuluh memberdayakan dirinya dengan dukungan dana, sarana, prasarana, dukungan politik dan kelembagaan berpengaruh pada kinerja penyuluhan. Kinerja yang menonjol waktu itu adalah meningkatnya produksi beras sampai Indonesia mengalami surplus dan mengekspornya ke negara lain. Permasalahannya adalah setelah pelaksanaan otonomi daerah perhatian terhadap penyuluh dan penyuluhan mulai menurun. Rendahnya perhatian pemda terhadap penyuluh dan penyuluhan menyebabkan motivasi penyuluh untuk mengembangkan kualitas kompetensinya juga menurun. Hal ini berakibat pada kinerja penyuluhan itu sendiri. Menurunnya kompetensi dan kinerja penyuluhan juga terkait dengan rendahnya dukungan lingkungan sosial, dukungan dan komitmen politik pemda, mandeg dan tidak berfungsi maksimalnya lembaga-lembaga penyuluhan baik di tingkat provinsi, kabupaten, kecamatan maupun desa/kelurahan. Berdasarkan latarbelakang dan permasalahan di atas, maka pertanyaan penelitiannya adalah: bagaimana pengaruh faktor-faktor internal dan eksternal penyuluh terhadap kinerja penyuluhan? Menjelaskan faktor-faktor yang berpengaruh terhadap kinerja penyuluhan.

\footnotetext{
* Korespondensi penulis. Telepon: 085283106993
} 


\section{METODE PENELITIAN}

Populasi penelitian ini adalah semua Penyuluh Pegawai Negeri Sipil (PNS) di Provinsi Nusa Tenggara Timur yang berjumlah 1.083 orang dan tersebar di 16 Kabupaten/Kota. Kategori penyuluh dibagi atas dua, yakni : (1) Penyuluh Terampil yang berlatarbelakang pendidikan SLTA (dalam hal ini SPMA) dan (2) Penyuluh Ahli yang berlatar belakang pendidikan Sarjana.

Lokasi sampel dipilih dengan teknik area sampling yaitu Kabupaten Kupang dan Timor Tengah Selatan mewakili pertanian lahan kering dan Kabupaten Manggarai mewakili wilayah pertanian lahan basah. Ada enam desa yang dipilih secara acak dari setiap kabupaten. Sampel penelitian yang menjadi unit analisis adalah penyuluh pertanian yang sedang bekerja di 18 desa binaan dan penyuluh pertanian yang pernah bekerja di 18 desa yang dipilih secara sengaja (purposive sampling). Dari teknik itu maka jumlah penyuluh yang dijadikan sample adalah: Kabupaten Kupang (22 orang penyuluh yang terdiri dari penyuluh terampil 15 orang dan penyuluh ahli 7 orang), Kabupaten Timor Tengah Selatan (28 penyuluh yang terdiri dari penyuluh terampil 20 orang dan penyuluh ahli 8 orang) dan Kabupaten Manggarai (22 penyuluh yang terdiri dari penyuluh terampil 15 orang dan penyuluh ahli 7 orang). Jumlah keseluruhan: 72 penyuluh.

Penelitian dilakukan dengan metode survey yang bersifat deskriptif kualitatif dan deskriptif kuantitatif. Dalam deskripsi kualitatif peneliti menjelaskan berbagai faktor yang mempengaruhi kompetensi penyuluh dalam melaksanakan tugas pokoknya baik sebagai hasil pengamatan maupun hasil wawancara mendalam dengan penyuluh dan pihak-pihak terkait. Dalam deskripsi kuantitatif peneliti menjelaskan hubungan pengaruh antara berbagai faktor dengan kompetensi untuk menguji hipotesa yang sudah dibuat sebelumnya.

Data penelitian terdiri dari data primer dan sekunder. Data primer diperoleh secara langsung dari responden (penyuluh pertanian) melalui pengisian questioner. Data primer juga diperoleh dari informan lain seperti atasan langsung penyuluh pertanian, penyelenggara diklat, unsur-unsur Pemda yang terkait. Data sekunder diperoleh dari berbagai literatur, hasil penelitian, peraturan perundangundangan dan data lain yang relevan dengan penelitian. Keseluruhan data penelitian tersebut dikaji dengan menggunakan analisis statistik didukung oleh analisis kualitatif untuk memperkuat dan mempertajam analisis kuantitatif yang ada sebagaimana yang dikatakan oleh Miller, 1991; Black dan Champion, 1976; Dey, 1993, Moleong, 1991, Sumardjo, 1999). Penelitian ini sejalan dengan pemikiran para ahli tersebut bahwa metoda yang digunakan pendekatan survai atau menggunakan paradigma kuantitatif sebagai tumpuan analisis, dilengkapi dengan informasi berdasarkan data kualitatif untuk mendukung dan mempertajam analisis kuantitatif yang ada. Penelitian berlangsung pada bulan Juni 2006 s/d November 2006.

Instrumen atau alat ukur yang digunakan dalam penelitian ini adalah quistioner yang berisi daftar pertanyaanpertanyaan yang berhubungan dengan peubah-peubah bebas (X) dan peubah tidak bebas (Y). Instrumentasi yang disusun itu mengikuti beberapa tahap sebagai berikut: (1) tahap uji coba instrumen. Sebelum dilakukan penyebaran questioner yang sesungguhnya, terlebih dahulu diadakan uji coba pengisian questioner pada responden penyuluh. Uji coba ini bertujuan untuk mengetahui gambaran umum dari penyebaran questioner selanjutnya dan tingkat pemahaman responden terhadap pertanyaan-pertanyaan yang diajukan.

Menurut Kerlinger (2002), validitas instrumen menunjukkan sejauh mana suatu alat ukur itu telah mengukur apa yang akan diukur. Titik berat dari uji coba validitas instrumen adalah pada validitas isi, yang dapat dilihat dari: (1) apakah instrumen tersebut telah mampu mengukur apa yang akan diukur, dan (2) apakah informasi yang dikumpulkan telah sesuai dengan konsep yang telah digunakan. Uji coba instrumen kepada 30 penyuluh Kabupaten Manggarai Flores kemudian dianalisis dengan menggunakan 
korelasi Product Moment (Arikunto, 1998)

HASIL DAN PEMBAHASAN yang hasilnya adalah Tabel 1 .

Tabel 1. Kisaran Nilai Koefisien Korelasi Uji Validitas Instrumen

\begin{tabular}{llc}
\hline No & Variabel & Kisaran koefisien Korelasi \\
\hline 1 & Karakter Individu Penyuluh (X1) & $0,735^{* *}-0,832^{* *}$ \\
2 & Diklat Penyuluhan(X2) & $0,634^{*}-0,798^{* *}$ \\
3 & Lingkungan (X3) & $0,675^{* *}-0,771^{* *}$ \\
4 & Struktur Organisasi Penyuluhan(X4) & $0,631^{* *}-0,762^{* *}$ \\
5 & Kompetensi Penyuluh (Y1) & $0,737 * 7_{-}-0,821^{* *}$ \\
6 & Kinerja Penyuluhan (Y2) & $0,746^{* *}-0,857^{* *}$ \\
\hline
\end{tabular}

Keterangan: $* *$ nyata pada $\mathrm{a}=0,01$.

Reliabilitas instrumen adalah indeks yang menunjukkan sejauh mana ketepatan alat tersebut untuk dapat dipercaya dan dapat diandalkan. Reliabilitas menunjukkan konsistensi suatu alat pengukur di dalam mengukur gejala yang sama (Singarimbun dan Effendi, 1989). Suatu alat pengukur dikatakan memiliki reliabilitas yang tinggi apabila reliabilitas alat tersebut memiliki sifat konsisten, ketepatan jika alat tersebut dipakai berulangkali terhadap suatu gejala yang sama walaupun dalam waktu yang berbeda. Hasil pengujian reliabilitas alat ukur menggunakan teknik belah dua, yaitu mengkorelasikan jawaban belahan pertama (ganjil) dan belahan kedua (genap). Rumus yang digunakan adalah:

r.total $=\frac{2(\mathrm{r} . \mathrm{tt})}{1+\mathrm{r} . \mathrm{tt}}$

dimana:

$r$-total $=$ angka realibilitas keseluruhan item atau koefisien realibilitas

r.tt = angka korelasi belahan pertama dan belahan kedua

Nilai Reliabilitas Guttman Split-Half adalah $0,756 \geq \mathrm{r}$ tabel, hal ini menunjukkan bahwa alat ukur tersebut mempunyai reliabilitas tinggi.

Data dianalisis dengan menggunakan statistik deskriptif. Untuk melihat hubungan pengaruh antara variabel digunakan SEM (Structural Equation Model).

\section{Karakteristik Responden Penyuluh Kabupaten Kupang}

Pada Gambar 1 dikemukakan sejumlah karakteristik responden penyuluh Kabupaten Kupang $(n=22$. penyuluh terampil $=15$, penyuluh ahli $=7$ ).

Dari Gambar 1 tampak bahwa sebagian besar penyuluh terampil di Kabupaten Kupang berpendidikan rendah (SPMA) dan semua penyuluh ahli berpendidikan tinggi (sarjana); sepertiga dari penyuluh berpendidikan diploma. Diklat penyuluhan rata-rata hanya 2,8 pelatihan untuk penyuluh terampil dan 6,2 diklat untuk penyuluh ahli setiap tahun. Kebanyakan penyuluh terampil berumur sekitar 31-44 tahun dengan rata-rata 36,2 tahun. Penyuluh ahli kebanyakan berusia relatif lebih muda antara 20-30 tahun dengan usia rata-rata 27,2 tahun. Penyuluh berusia relatif tua (di atas 45 tahun) jumlahnya tidak banyak, dengan rata-rata usia 48,5 tahun. Sebagian besar penyuluh adalah laki-laki dengan bidang keahlian yang dominan pertanian. Sebagian besar penyuluh terampil dan penyuluh ahli memiliki masa kerja yang relatif sedang berkisar dari 6-14 tahun dengan rata-rata 9,1 tahun. Kebanyakan penyuluh ahli memiliki sifat kosmopolitan yang tinggi dibandingkan dengan penyuluh terampil. Dari aspek pendapatan, sebagian besar penyuluh berpendapatan sedang atau menengah dengan rata-rata 1,4 juta per bulan. Dari aspek motivasi, penyuluh terampil lebih termotivasi dalam bekerja dan meningkatkan kompetensi oleh dorongan atau motivasi ekstrinsik seperti uang, jabatan, karir dan sebagainya. Berbeda 


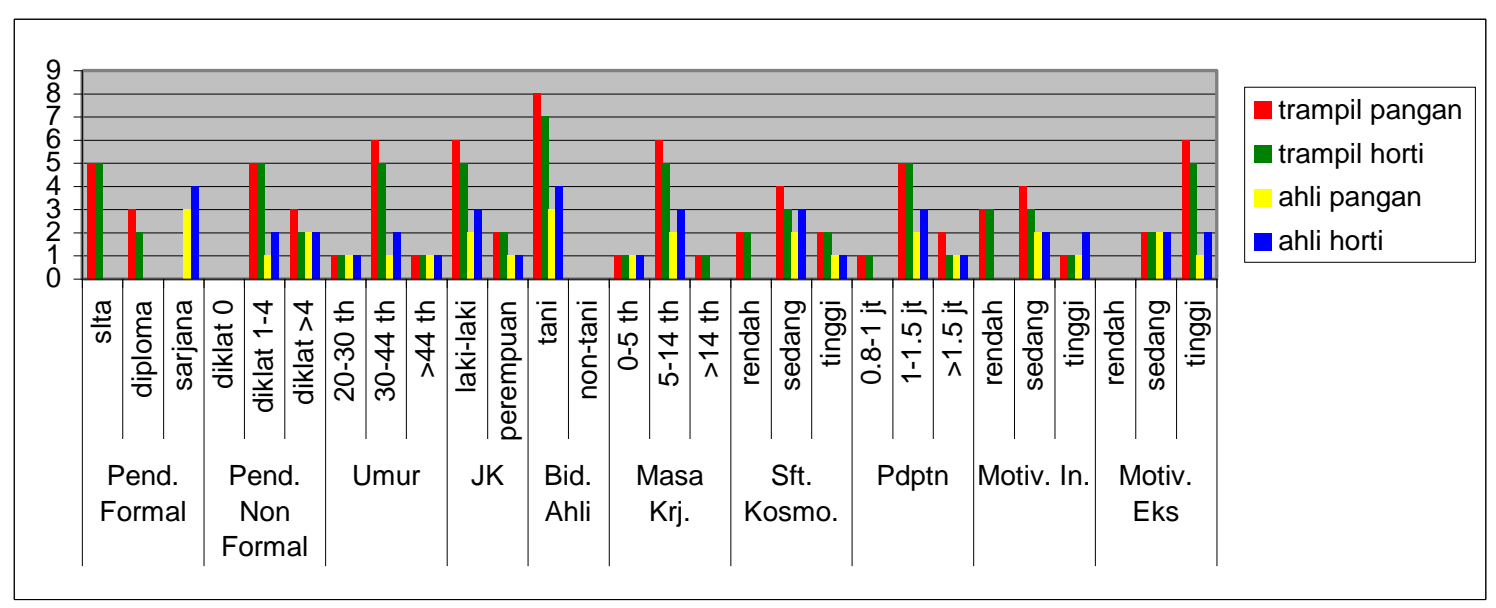

Gambar 1. Karakteristik individu Penyuluh Kabupaten Kupang

dengan penyuluh ahli yang lebih termotivasi oleh motivasi intrinsik.

\section{Karakteristik Responden Penyuluh Kabupaten Timor Tengah Selatan}

Pada Gambar2 dikemukakan karakteristik responden penyuluh Kabupaten Timor Tengah Selatan $(n=28$, penyuluh terampil $=20$, penyuluh ahli=8).

Dari Gambar 2 tampak bahwa sebagian besar penyuluh terampil berbasis Sekolah Menengah Pertanian Pertama (SPMA) dan penyuluh ahli berpendidikan Sarjana. Baik penyuluh terampil maupun ahli telah mengikuti diklat berkisar di antara 1-4 kali dengan rata-rata 2,7diklat/orang/tahun. Kebanyakan penyuluh ahli tergolong usia muda (20-30 tahun dengan rata-rata usia 28,2 tahun). Kurang dari separuh penyuluh terampil berusia sedang (31-44 tahun dengan usia rata-rata 32,3 tahun). Sebagian besar penyuluh adalah laki-laki dengan bidang keahlian yang homogen (pertanian). Masa kerja sebagian besar penyuluh terampil dan penyuluh ahli berkisar antara 6-14 tahun dengan rata-rata 8,8 tahun. Penyuluh ahli pada umumnya memiliki sifat kosmopolitan tinggi dibandingkan dengan penyuluh terampil. Dari segi pendapatan, sebagian besar penyuluh terampil dan penyuluh ahli berpendapatan menengah berkisar di antara Rp.1,1 sampai Rp. 1, 5 juta dengan rata-rata Rp.1,478.000. Dari segi motivasi, penyuluh terampil lebih didorong oleh motivasi ekstrinsik, sebaliknya penyuluh ahli lebih karena adanya motivasi intrinsik.

\section{Karakteristik Responden Penyuluh}

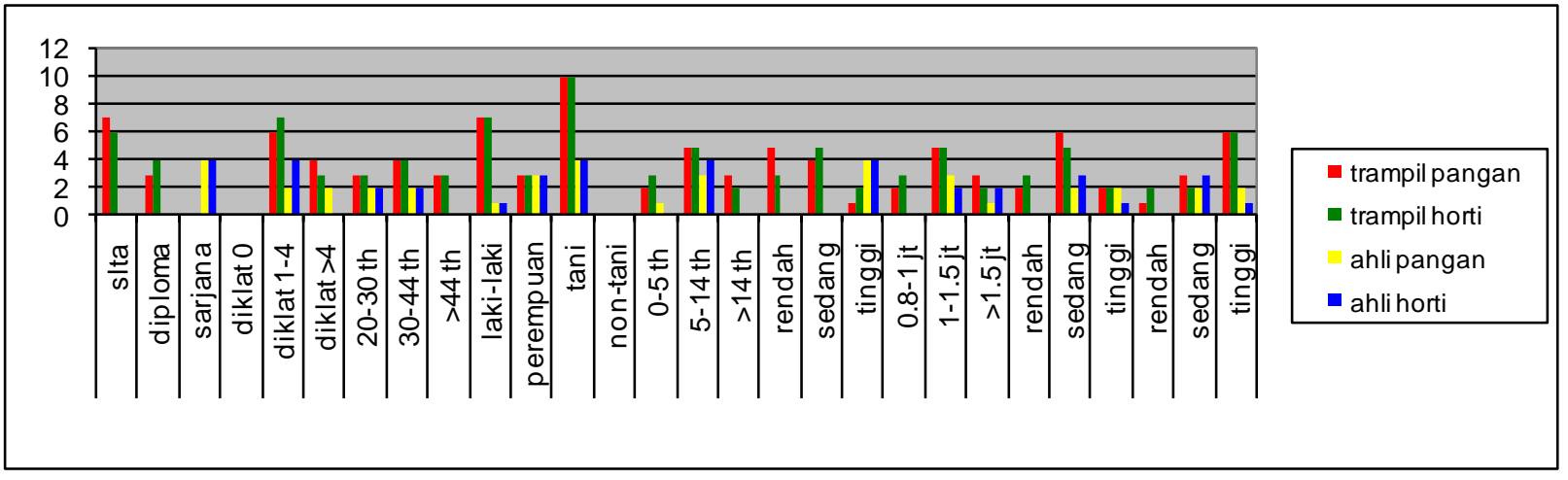




\section{Kabupaten Manggarai}

Pada Gambar 3 dikemukakan karakteristik individu penyuluh Kabupaten Manggarai ( $\mathrm{n}=22$, P.terampil=15, P. ahli=7).

Dari Gambar 3 terlihat bahwa semua penyuluh terampil di Kabupaten Manggarai berpendidikan rendah (Sekolah Pertanian Menengah Atas) dan semua penyuluh ahli berpendidikan tinggi (Sarjana). Sebagian besar penyuluh terampil ini telah mengikuti 1 - 4 kali diklat dengan rata-rata 2,9 diklat/orang/tahun. Sebagian besar penyuluh ahli telah mengikuti diklat $>4$ kali dengan ratarata 5,5 diklat/orang. Sebagian besar penyuluh terampil berusia sekitar 31 - 44 tahun dengan usia rata-rata 33,4 tahun; separuh dari penyuluh ahli berusia sekitar 31-44 tahun dengan usia rata-rata 32,1 tahun. Sebagian besar penyuluh terampil dan ahli adalah lakilaki dengan masa kerja berkisar 6-14 tahun (rata-rata masa kerja 9,2 tahun). Sebagian besar penyuluh terampil dan ahli mempunyai sifat kosmopolitan sedang. Dari segi pendapatan sebagian besar dari mereka mengembangkan pengetahuan kebanyakan dari penyuluh terampil lebih didorong oleh motivasi ekstrinsik seperti jabatan, uang, kebutuhan-kebutuhan materi. Sebaliknya sebagian besar penyuluh ahli lebih terdorong oleh motivasi intrinsik seperti ingin mencapai prestasi dalam pengetahuan dan pengakuan dari orang lain.

\section{Pengaruh Faktor Internal dan Eksternal Penyuluh terhadap Kinerja Penyuluhan}

Dugaan pengaruh karakter individu penyuluh, diklat penyuluhan, lingkungan, struktur organisasi penyuluhan, kompetensi penyuluh terhadap kinerja penyuluhan dianalisis dalam dua periode waktu yakni periode sebelum otonomi daerah dan sesudah otonomi daerah. Pengkajian dalam dua periode ini sengaja dilakukan untuk melihat perbedaan di antara kedua periode itu. Analisis pengaruh kelima faktor itu dibuat dengan menggunakan model SEM (Structural Equation Model). Melalu model ini dapat diketahui pengaruh atau hubungan antara konstruk secara kausalitas. Dari hasil uji analisis dengan meng-

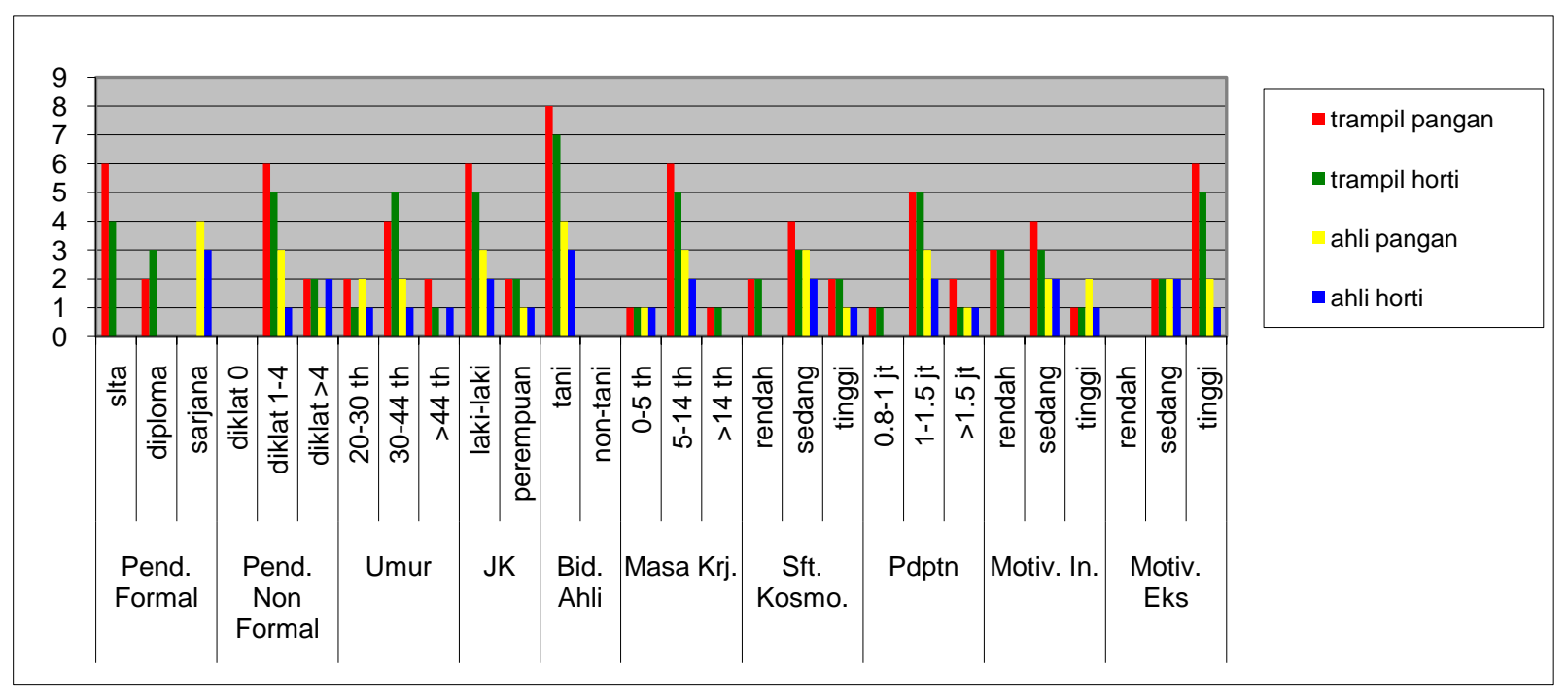

Gambar 3. Karaktersitik individu Penyuluh Kabupaten Manggarai

berpendapatan menengah berkisar antara Rp.1,1 juta - Rp.1,5 juta/bulan dengan ratarata pendapatan Rp.1.470.000. Dalam gunakan model SEM, maka hubungan pengaruh antara keenam variabel itu secara keseluruhan tampak seperti dalam Gambar 4. 


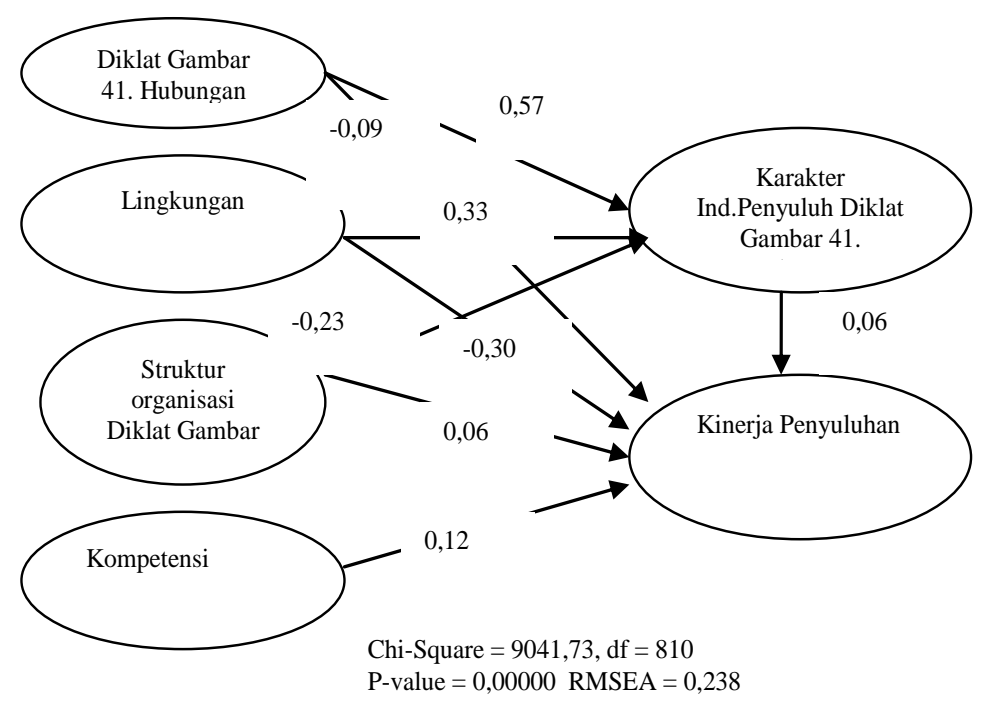

Gambar 4. Model Hubungan antara Variabel secara Lebih Ringkas

Dari hasil analisis SEM karakter individu penyuluh berpengaruh negatif terhadap kinerja penyuluhan (koefisien pengaruh $0,06$, t-hitung $0,066<1,96)$. Diklat penyuluhan berpengaruh positif nyata terhadap karakter individu penyuluh (koefisien pengaruh 0,57), namun berpengaruh negatif terhadap kinerja penyuluhan (koefisien pengaruh -0,09). Variabel lingkungan juga berpengaruh positif nyata terhadap karakter individu penyuluh, namun berpengaruh negatif terhadap kinerja penyuluhan $(-0,30)$. Struktur organisasi penyuluhan berpengaruh negatif terhadap karakter individu penyuluh (,23) dan kinerja penyuluhan $(0,06)$. Kompetensi penyuluh juga kecil sekali pengaruhnya terhadap kinerja penyuluhan $(0,12)$.

Setelah pelaksanaan otonomi daerah hubungan pengaruh antara variabel itu tampak dalam Gambar 5.

Dari hasil uji SEM menunjukkan bahwa setelah wewenang penyuluhan dilimpahkan ke daerah, dari lima variabel yakni karakter individu penyuluh, diklat penyuluhan, lingkungan, kompetensi dan struktur organisasi penyuluhan, hanya struktur organisasi penyuluhan dan diklat penyuluhan yang berpengaruh nyata terhadap kinerja penyuluhan (masing-masing koefisien pengaruh 1,33, t-hitung 2,53 >1,96 dan koefisien pengaruh 1,73, t-hitung $1,97>1,96$ ) sedangkan tiga variabel lain yaitu karakter individu penyuluh, lingkungan dan kompetensi penyuluh berpengaruh negatif terhadap kinerja penyuluhan masing-masing karakter individu penyuluh (koefisien pengaruh -0,90, t-hitung $0,15<1,96$, variabel lingkungan (koefisien pengaruh 0,12 , t-hitung $1,39<1,96)$; dan kompetensi penyuluh (koefisien pengaruh 0,05 , t-hitung $-0,63<1,96$ ).

Karakteristik Individu Penyuluh. Sebagian besar penyuluh $(>50 \%)$ di tiga kabupaten penelitian berpendidikan rendah (SLTA) dan sisanya berpendidikan sedang (diploma) dan tinggi (sarjana). Semua penyuluh ahli di tiga kabupaten berpendidikan tinggi (sarjana) dan pada umumnya lebih banyak mengikuti diklat daripada penyuluh terampil. Tidak meratanya kesempatan mengikuti diklat ini menyebabkan kinerja penyuluh terampil di lapangan tidak sebaik penyuluh ahli apalagi motivasi mereka pada umumnya lebih kuat disebabkan oleh motivasi ekstrinsik seperti uang, kepangkatan dan jabatan sedangkan penyuluh ahli pada umumnya lebih didorong oleh motivasi intrinsik yakni ingin mencapai prestasi dan pengakuan (recognition) dari orang lain. Baik 


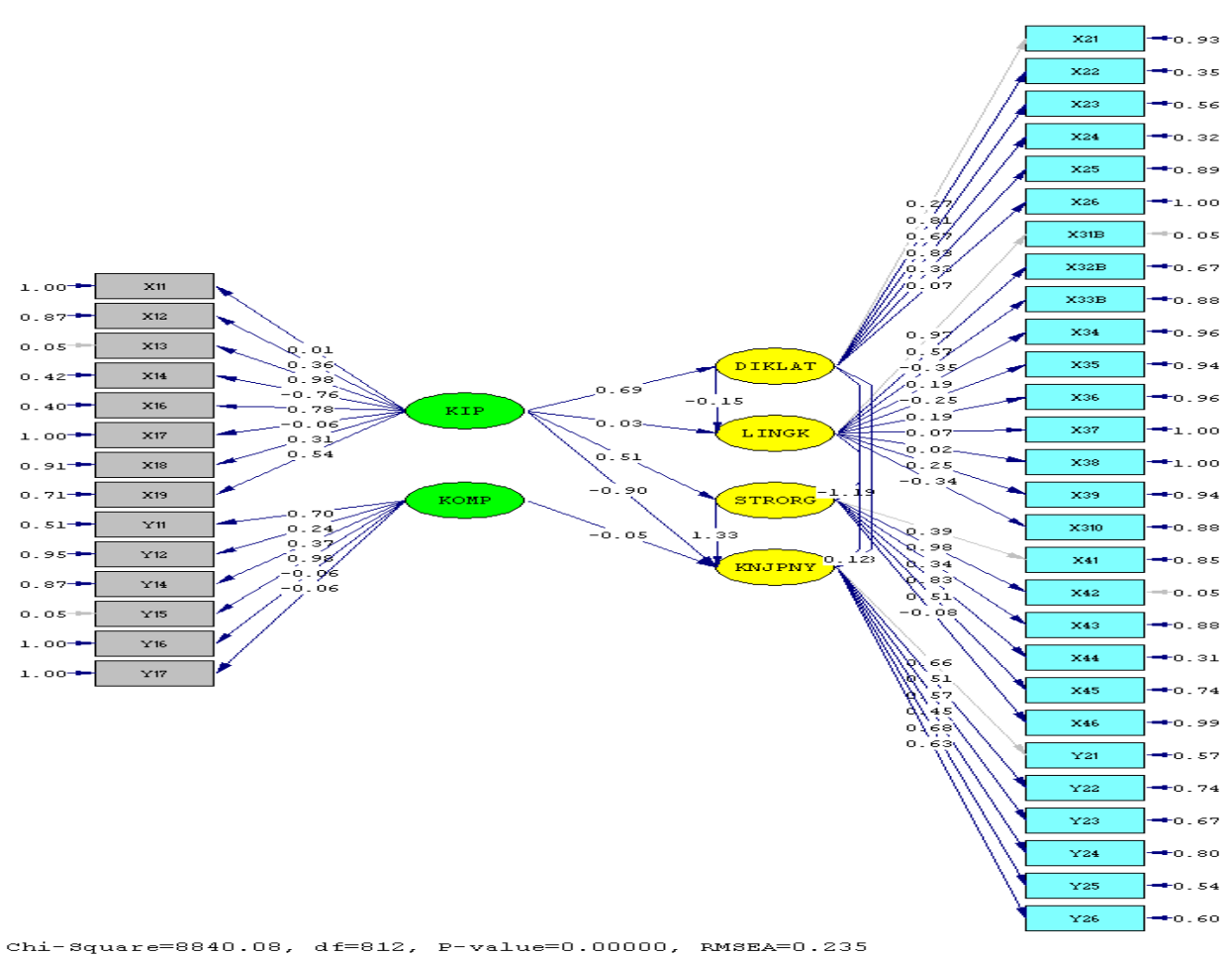

Keterangan:

$\mathrm{X} 1$ = Karakter Individu Penyuluh (KIP): X11= Pendidikan Formal, X12= Pendidikan Non Formal, X13= Umur, X14= Jenis Kelamin, X15= Bidang Keahlian, X16= Masa Kerja, X17= Sifat Kosmopolitan, X18= Pendapatan Ekonomi, X19= Motivasi (ntrinsik dan ekstrinsik) X2 = Diklat Penyuluhan : X21 = Kurikulum, X22= Pengalaman belajar, X23= Kompetensi Widyaiswara, X24= Komitmen Pengelola, X25= Sistim Evaluasi dan $\mathrm{X} 26=$ Dukungan dana, sarana dan prasarana $\mathrm{X} 3=$ Lingkungan : X31a= Dukungan politik sebelum otonomi daerah $\mathrm{X} 31 \mathrm{a}=$ Dukungan pemda sebelum otonomi daerah X3a= Dukungan dana, sarana dan prasarana sebelum otonomi daerah, X34= Perubahan Paradigma Penyuluhan, X35= Dukungan Masyarakat (kampus. LSM), X36= Dukungan Keluarga, X37= Dukungan Sumber Informasi, X38= Topografi dan Iklim X39= Teknologi Pertanian dan X4 = Struktur Organisasi Penyuluhan; X41= Ukuran Organisasi Penyuluhan, X42= Pengawasan, $\mathrm{X} 43=$ Struktur Wewenang, $\mathrm{X} 44=$ Struktur Komunikasi, X45 $=$ Pola Kepemimpinan dan X46= Sistim 'reward and punishment'. Y1 $=$ Kompetensi Penyuluh, Y11 = Kompetensi Menyiapkan Penyuluhan, Y12= Kompetensi Melaksanakan Penyuluhan, Y13= Kompetensi Membuat Evaluasi dan Laporan Penyuluhan, Y14= Kompetensi Mengembangkan Profesionalisme, Y15 Komperensi mengembangkan Penyuluhan, Y16= Kompetensi Berkomunikasi, Y17= Kompetensi Berinteraksi Sosial ; Y2= Kinerja Penyuluhan. Y21= Manfaat organisasi penyuluhan, Y22= Kesesuaian materi penyuluhan dengan kebutuhan petani, $Y 23=$ Kepuasan petani atas penerapan metode penyuluhan, $Y 24=$ Manfaat kelompok tani dan lembaga ekonomi tani, Y25= Manfaat kepemimpinan tani, wanita dan pemuda tani, Y26= Kepuasan petani atas kompetensi penyuluh

Gambar 5. Hubungan antara Kompetensi Penyuluh, Karakter Individu Penyuluh, Diklat Penyuluhan, Lingkungan, Struktur Organisasi dan Kinerja Penyuluhan (Setelah Otonomi Daerah)

penyuluh ahli maupun penyuluh terampil sebagian besar adalah laki-laki dan pada umumnya hanya memiliki keahlian di bidang pertanian ("on farm"). Pendapatan sebagian besar penyuluh tergolong cukup sesuai dengan standar sebagai Pegawai Negeri Sipil dihitung atas dasar masa kerja dan kepangkatannya.

Berdasarkan hasil uji SEM di atas, baik sebelum maupun sesudah pelaksanaan otonomi daerah karakteristik individu penyuluh berpengaruh negatif terhadap kinerja penyuluhan. Sebelum otonomi daerah penyuluh menempatkan diri sebagai "alat" atau perpanjangan tangan pemerintah dalam rangka menyukseskan kebijakan nasional di bidang pertanian yang berorientasi pada peningkatan produksi pangan. Di depan kelompok sasaran penyuluh menempatkan diri sebagai "alat" pemerintah yang instruktif, 'bersifat memaksa' dan hampir tidak berusaha menumbuhkan partisipasi dari bawah (masyarakat). Pembentukan kelompok tani, kepemimpinan tani, lembaga ekonomi tani, materi dan metode-metode penyuluhan, organisasi penyuluhan semuanya berasal dari 
atas (pemerintah) dan hampir tidak melibatkan partisipasi dari bawah (masyarakat). Karena tidak berasal dari masyarakat maka kelompok tani, kepemimpinan tani, wanita tani dan pemuda tani, lembaga ekonomi tani, organisasi penyuluhan dan sebagainya tidak bertahan lama.

Di era otonomi daerah sejalan dengan rendahnya perhatian pemerintah daerah terhadap kegiatan penyuluhan, kinerja penyuluhan mengalami stagnasi yang luar biasa. Peran organisasi penyuluhan sebagai pemasok jasa-jasa informasi penyuluhan tidak berjalan, materi penyuluhan yang biasanya tersusun secara sistematis dalam bentuk programa penyuluhan sudah tidak ada, kelompok tani dan lembaga ekonomi tani yang dibentuk atas inisiatif penyuluh juga terbengkalai. Fungsi kepemimpinan tani, wanita tani dan pemuda tani juga mengalami kemunduran. Penyuluh yang di mata kelompok sasaran (petani) lebih dilihat sebagai sosok Pegawai Negeri Sipil tidak lagi bisa tampil dengan penuh percaya diri. Adanya ketidakpercayaan masyarakat kepada penyuluh menambah melemahnya motivasi penyuluh dalam bekerja.

Diklat Penyuluhan. Sebelum otonomi daerah diklat penyuluhan berpengaruh negatif terhadap kinerja penyuluhan (Gambar 4 ). Sebelum otonomi daerah kurikulum diklat cendrung bersifat seragam secara nasional dan memuat materi-materi penyuluhan yang kurang sesuai dengan karakteristik masyarakat setempat. Dari segi proses pendidikan kurikulum diklat mampu meningkatkan kompetensi penyuluh, namun kompetensi yang dihasilkan itu kurang mampu menghasilkan kinerja penyuluhan yang diharapkan. Di era otonomi daerah diklat penyuluhan berpengaruh positif terhadap kinerja penyuluhan. Kendatipun Balai Diklat di daerah masih merupakan Unit Pelaksana Teknis Kediklatan pemerintah pusat, namun dengan adanya "semangat" otonomi daerah lembaga diklat ini mulai menyesuaikan kurikulum, sistem penyelenggaraan, metoda pelatihan, dan sebagainya, dengan kebutuhan masyarakat lokal. Adanya adaptasi ini menghasilkan pengaruh nyata antara diklat penyuluhan dengan kinerja penyuluhan (koefisien 1,73 , thitung $1,97>1,96)$. Sebelum diklat diadakan, Balai Diklat sudah mulai mengkaji "need assesment" dari kabupaten/kota yang karakteristiknya berbeda-beda satu sama lain. Walaupun belum sepenuhnya sempurna namun penyuluh menilai sudah mulai ada perubahan ke arah penyelenggaraan diklat yang positif. Sebagai hasil proses belajar diklat yang reformatif pola pembentukan dan pengembangan kelompok tani, lembaga ekonomi, kepemimpinan tani, wanita tani dan pemuda tani tidak lagi dominan sebagai hasil inisiatif penyuluh tetapi lebih mengutamakan inisiatif masyarakat petani sendiri sesuai dengan kebutuhannya; penyuluh hanya bertindak sebagai fasilitator yang memberikan motivasi.

Lingkungan. Sebelum otonomi daerah perhatian terhadap penyuluhan baik oleh pemerintah pusat maupun pemerintah daerah dirasakan oleh penyuluh cukup besar. Hal ini terindikasi dengan disediakannya berbagai infrastruktur di pedesaan-pedesaan, lembagalembaga keuangan, sumberdaya manusia (penyuluh, peneliti, tokoh-tokoh LSM, dan sebagainya.), jasa dan fasilitas informasi, teknologi pertanian, dan sebagainya. Namun ternyata semua dukungan berbagai sumberdaya ini tidak dengan sendirinya meningkatkan kinerja penyuluhan. Sumberdaya-sumberdaya ini berpengaruh nyata terhadap karakteristik individu penyuluh dan potensi penyuluh mampu dikembangkan, namun tidak berarti berimbas pada kinerja penyuluhan. Kegiatan penyuluhan sebagai gerakan nasional terlihat 'semarak dan meyakinkan" di mata penyelenggara negara, namun di tingkat masyarakat mobilisasi nasional ini tetap menjadi gerakan "top down" yang sifatnya lebih menguntungkan elite kekuasaan dan bukan pada kelompok sasaran. Para penyuluh menilai bahwa penerimaan petani (kelompok sasaran) terhadap gerakan massal ini lebih bersifat "terpaksa" dan sama sekali belum mampu secara radikal memberikan daya kepada petani untuk keluar dari lingkaran kemiskinannya. Peningkatan produksi pangan tahun 1984 tidak berarti peningkatan kesejahteraan petani; petani tetap tertinggal 
dan miskin seperti sebelum adanya gerakan massal ini (Slamet, 2003).

Sesudah wewenang penyuluhan diberikan kepada daerah sesuai dengan prinsip otonomi, pemerintah pusat tidak lagi melakukan intervensi terhadap kegiatan penyuluhan. Dana dan pengadaan sarana serta prasarana penyuluhan diserahkan oleh pusat kepada daerah dalam kesatuan dengan DAU (Dana Alokasi Umum) dan DAK (Dana Alokasi Khusus). Pada pihak lain sejalan dengan penyelenggaraan pemerintahan di daerah yang menekankan otonomi, pemerintah daerah kurang memberikan perhatian kepada pembangunan pertanian dan penyuluhan. Perhatian pemda yang rendah ini dapat dilihat dari jumlah Anggaran Pendapatan dan Belanja Daerah (APBD I dan APBD II) untuk penyuluhan. Di tingkat Provinsi Nusa Tenggara Timur besarnya biaya untuk kegiatan penyuluhan tahun 2005 hanya Rp. 195.567.000 dan tahun 2007 meningkat sedikit menjadi Rp. 777.676.200. Besaran anggaran APBD I ini sangat tidak mencukupi untuk menangani kegiatan penyuluhan di 16 kabupaten/kota seperti mendukung peran organisasi penyuluhan sebagai pemasok jasa informasi penyuluhan bagi petani, pemberdayaan kelompok tani, lembaga ekonomi tani, kepemimpinan tani, wanita dan pemuda tani, dan pengembangan kompetensi penyuluh. Di tiga kabupaten lokasi penelitian dukungan Anggaran Pendapatan dan Belanja Daerah melalui APBD II untuk kegiatan yang sama juga masih terbatas.

\section{Struktur organisasi penyuluhan.} Sebelum otonomi daerah kelembagaan penyuluhan sangat rapi dan sistematis dari tingkat pusat sampai daerah bahkan desa. Namun struktur birokrasi yang sistematis dan berjenjang ini ternyata kecil sekali pengaruhnya terhadap kinerja penyuluhan bahkan bisa dikatakan tidak ada pengaruh sama sekali $(0,06)$. Adanya sistem komando, struktur wewenang yang ketat dengan pola kepemimpinan yang cenderung instruktif di setiap tingkatan wilayah menyebabkan pelaporan kegiatan cenderung kurang obyektif. Rasa takut terhadap sanksi atasan organisasi menyebabkan masyarakat diinstruksikan untuk melaksanakan kebijakan penyuluhan di bawah pengawasan penyuluh secara ketat. Keseluruhan kinerja penyuluhan seperti peran organisasi penyuluhan sebagai pemasok jasa informasi penyuluhan bagi petani, pembentukan kelompok tani, lembaga ekononomi tani, kepemimpinan tani, wanita tani dan pemuda tani dimobilisasi dengan kekuatan yang bersifat memaksa walaupun sesungguhnya kelompok sasaran (dalam hal ini masyarakat petani) tidak menghendakinya. Mereka mengikutinya dengan perasaan terpaksa karena sudah menjadi ketentuan umum.

Di era otonomi daerah berdasarkan uji SEM di atas struktur organisasi penyuluhan berpengaruh positif nyata terhadap kinerja penyuluhan (koefisien pengaruh 1,33, $\mathrm{t}$-hitung $2,53>1,96$. Dengan disahkannya UndangUndang Penyuluhan pada bulan November tahun 2006 yang lalu yang di antaranya memuat penataan kembali lembaga-lembaga penyuluhan yang selama ini tidak teratur mendorong semangat dan motivasi kerja para pejabat yang membawahi kegiatan penyuluhan. Para penyuluh pun termotivasi untuk meningkatkan kinerjanya. Walaupun di Kabupaten Kupang dan Timor Tengah Selatan kelembagaan penyuluhan hanyalah berbentuk salah satu sub dinas dari Dinas Pertanian dan di Kabupaten Manggarai berbentuk Kantor dengan nama Kantor Informasi Penyuluhan Pertanian (KIPP), namun mereka berusaha menunjukkan kemampuannya dalam menangani penyuluhan di daerah. Balai Penyuluhan Pertanian (BPP) yang selama ini tidak berfungsi mulai difungsikan kembali dan mereka secara aktif mulai mendekati kelompok sasaran (petani).

Kompetensi Penyuluh. Sebelum otonomi daerah penyuluh mampu menerapkan kompetensinya dalam melaksanaan tugas seperti menyiapkan penyuluhan, melaksanakan penyuluhan, membuat evaluasi dan pelaporan penyuluhan, mengembangkan penyuluhan dan mengembangkan profesionalismenya dan semua dimensi itu berpengaruh positif nyata terhadap kinerja penyuluhan walaupun pengaruh tersebut relatif kecil $(0,12)$. Di era sebelum otonomi daerah pekerjaan penyuluh 
sudah digariskan dengan jelas, terarah dan disiplin serta diawasi secara ketat oleh pimpinannya. Pengawasan yang ketat dengan sistem pelaporan aktivitas penyuluhan yang berjenjang dari desa ke kecamatan, kecamatan ke kabupaten, kabupaten ke provinsi dan provinsi ke pusat ini "memaksa" penyuluh bekerja ekstra ketat dan purna waktu. Kondisi kerja yang berada di bawah tekanan psikologis ini mempengaruhi mutu kerja mereka. Dari uji SEM ternyata kompetensi para penyuluh dalam melaksanakan tugas tidak mampu menghasilkan kinerja penyuluhan yang memuaskan. Aktivitas penyuluhan kepada petani, pembentukan dan pengembangan kelompok tani, lembaga ekonomi tani, kepemimpinan tani, wanita dan pemuda tani ternyata kurang memberikan dampak yang positif bagi petani. Kebijakan penyuluhan yang berasal dari 'atas" (pemerintah) ini dan kurang melibatkan partisipasi masyarakat sendiri ternyata mengalami resistensi oleh masyarakat sendiri.

Di era otonomi daerah saat motivasi penyuluh menurun drastis karena kurangnya perhatian pemda terhadap penyuluh dan penyuluhan, penyuluh hampir tidak lagi melaksanakan tugas-tugasnya. Di tengah penyuluhan yang macet dan mengalami stagnasi, penyuluh menjadi tidak berdaya dan berpengaruh pada kinerja penyuluhan secara keseluruhan. Uji SEM menunjukkan kompetensi penyuluh berpengaruh negatif terhadap kinerja penyuluhan $(-0,05)$.

\section{KESIMPULAN}

Karakteristik individu penyuluh baik sebelum maupun sesudah otonomi daerah berpengaruh negatif terhadap kinerja penyuluhan. Sebelum otonomi daerah, potensipotensi individual penyuluh digerakkan bersamaan dengan sifat penyuluhan yang "top down" dan "berasal dari atas". Di era otonomi daerah, potensi-potensi individual penyuluh yang sama justru kurang diberdayakan oleh pemda sejalan dengan rendahnya perhatian pemda terhadap penyuluh dan penyuluhan.

Sebelum otonomi daerah diklat penyuluhan yang sentralistis dan seragam diatur oleh
Pusat (kurikulum, materi, dan sebagainya) dan kurang beradaptasi dengan kebutuhan masyarakat lokal ternyata berpengaruh negatif terhadap kinerja penyuluhan. Sesudah otonomi daerah adanya kritik terhadap pola penyelenggaraan diklat baik secara internal maupun eksternal mendorong adanya perbaikan sehingga berpengaruh positif nyata terhadap kinerja penyuluhan.

Sebelum otonomi daerah aspek-aspek lingkungan seperti komitmen pemerintah pusat, komitmen pemda terhadap penyuluhan ternyata berpengaruh negatif terhadap kinerja penyuluhan. Kebijakan yang bersifat instruktif dan satu arah (dari atas) ternyata kurang dapat diterima oleh masyarakat. Sesudah otonomi daerah, rendahnya perhatian pemda terhadap penyuluhan baik dalam bentuk dukungan politik, dana, sarana, prasarana, fasilitas, informasi dan teknologi berpengaruh negatif terhadap kinerja penyuluhan.

Sebelum otonomi daerah struktur organisasi penyuluhan yang sistematis dari pusat sampai desa, formal, birokratis dengan sistem pelaporan yang berjenjang di bawah pengawasan ketat pimpinan masing-masing strata ternyata menimbulkan tekanan psikologis tersendiri bagi penyuluh dan hal itu berpengaruh negatif terhadap kinerja penyuluhan. Sesudah otonomi daerah adanya perhatian terhadap penataan struktur organisasi penyuluhan sebagaimana yang diamanatkan oleh Undang-Undang Penyuluhan setelah bertahun-tahun kelembagaan tersebut tidak ditata secara jelas memotivasi pejabat dan penyuluh meningkatkan kinerjanya.

Sebelum otonomi daerah penyuluh bekerja dalam suasana yang disiplin, ketat, birokratis dan hal itu mempengaruhi kompetensinya dalam melaksanakan tugas. Mereka bekerja dalam tekanan psikologis yang cukup tinggi dengan adanya berbagai kewajiban seperti membuat pelaporan mingguan, bulanan, tribulanan, dsb, di samping mengunjungi kelompok sasaran secara berkala melalui sistem LAKU. Ternyata pelaksanaan tugas tersebut berpengaruh negatif terhadap kinerja penyuluhan. Mereka bekerja dengan pola "Asal Bapak Senang". Setelah otonomi daerah kompetensi penyuluh jelas-jelas tidak 
dikembangkan secara maksimal dan berakibat negatif pada kinerja penyuluhan.

\section{DAFTAR PUSTAKA}

Black, James A, dan D.J. Champion, 1976. Method and Issues in Sosial Research. New York : John Wiley \& Sons.

Dey, Ian. 1993. Qualitative Data Analysis: A User-Friendly Guide for Sosial Scientists. New York : Routledge.

Miller, Delbert C. 1991. Handbook of Research Design and Sosial Measurement. Fifth Edition. London: Sage Publication.

Moleong, Lexy J. 1991. Metodologi Penelitian Kualitatif. $\quad$ Bandung: Remaja Posdakarya.

Slamet, Margono. 2003. Paradigma Baru Penyuluhan Pertanian di Era Otonomi Daerah. Dalam Membentuk Pola Perilaku Manusia Pembangunan. Diedit oleh Ida Yustina dan Adjat Sudradjat. Bogor: IPB Press.

Singarimbun, M. dan S. Effendi, 1989. Metode Penelitian Survey. Cetakan pertama. Jakarta: LP3ES.

Sumardjo. 1999. Transformasi Model Penyuluhan Pertanian menuju Pengembangan Kemandirian Petani. Kasus di Provinsi Jawa Barat. Disertasi. Bogor: Program Studi Ilmu Penyuluhan Pembangunan Program Pasca Sarjana Institut Pertanian Bogor.

Wardoyo. 1992. Pendekatan Penyuluhan Pertanian Untuk Meningkatkan Partisipasi Masyarakat. Dalam Penyuluhan Pembangunan Indonesia: Menyongsong Abad XXI. Diedit oleh Aida Vitayala Sjafri Hubeis dengan kawan-kawan. Jakarta: PT Pustaka Pembangunan Swadaya Nusantara. 